University of Wollongong

Research Online

Faculty of Business - Papers (Archive)

Faculty of Business and Law

$1-1-2016$

Board diversity and corporate social disclosure: evidence from Vietnam

Trang Cam Hoang

Ton Duc Thang University, tch855@uowmail.edu.au

Indra Abeysekera

Central Queensland University, indraa@uow.edu.au

Shiguang Ma

University of Wollongong, shiguang@uow.edu.au

Follow this and additional works at: https://ro.uow.edu.au/buspapers

Part of the Business Commons

Research Online is the open access institutional repository for the University of Wollongong. For further information contact the UOW Library: research-pubs@uow.edu.au 


\title{
Board diversity and corporate social disclosure: evidence from Vietnam
}

\begin{abstract}
Debates around sound corporate governance propose board diversity as a key attribute to sufficiently challenge executive management for stakeholder engagement. This study contributes to this debate by empirically investigating the effect of board diversity on corporate social disclosure (CSD) of Vietnamese listed firms. The study finds a significantly positive effect of diversity-in-boards (dissimilarities among directors within a board, i.e., demographic attributes of board members) on CSD while diversity-of-boards (dissimilarities among firm boards, i.e., board structure) has no effect on CSD. The results contribute by showing that a single theoretical approach can provide an adequate explanation for board diversity. The study contributes methodologically by demonstrating the design and measurement of board diversity indices, and a three-dimensional stakeholder-relevant CSD index. The findings benefit regulators and corporate executives in better understanding firms' CSD practices and stakeholders' expectations.
\end{abstract}

\section{Disciplines}

Business

\section{Publication Details}

Hoang, T. Cam., Abeysekera, I. \& Ma, S. (2016). Board diversity and corporate social disclosure: evidence from Vietnam. Journal of Business Ethics, Online First 1-20. 


\title{
Board Diversity and Corporate Social Disclosure:
}

\section{Evidence from Vietnam}

\author{
Trang Cam Hoang ${ }^{1}$, Indra Abeysekera ${ }^{2}$, Shiguang $\mathrm{Ma}^{3}$
}

\begin{abstract}
Debates around sound corporate governance propose board diversity as a key attribute to sufficiently challenge executive management for stakeholder engagement. This study contributes to this debate by empirically investigating the effect of board diversity on corporate social disclosure (CSD) of Vietnamese listed firms. The study finds a significantly positive effect of diversity-in-boards (dissimilarities among directors within a board, i.e., demographic attributes of board members) on CSD while diversity-of-boards (dissimilarities among firm boards, i.e., board structure) has no effect on CSD. The results contribute by showing that a single theoretical approach can provide an adequate explanation for board diversity. The study contributes methodologically by demonstrating the design and measurement of board diversity indices, and a three-dimensional stakeholder-relevant CSD index. The findings benefit regulators and corporate executives in better understanding firms' CSD practices and stakeholders' expectations.
\end{abstract}

Key words: board of directors, corporate social disclosure, diversity, diversity-in-boards, diversity-of-boards, Vietnam.

\footnotetext{
${ }^{1}$ Trang Cam Hoang, Faculty of Accounting, Ton Duc Thang University, Vietam. hoangcamtrang@tdt.edu.au

${ }^{2}$ Indra Abeysekera, S P Jain School of Management, Australia. indraabeysekera@ gmail.com

${ }^{3}$ Shiguang Ma, School of Accounting, Economics and Finance, University of Wollongong, Australia, Shiguang@uow.edu.au
} 


\section{Introduction}

A board of directors is the cornerstone of corporate governance frameworks. There are numerous factors that signify various dimensions of a board, and board diversity is one of the most important (Kang et al. 2007, Milliken and Martins 1996). The breadth of factors relating to board diversity make it difficult to define the term explicitly (Harrison and Klein 2007). Several scholars have examined the implications of board diversity in relation to firm's outcomes by defining it operationally (Hafsi and Turgut 2013). Some studies refer to board diversity as a demographic phenomenon entailing age, gender, and ethnicity, while others refer to board diversity as a structural phenomenon comprising CEO duality, board independence, and director ownership. Hafsi and Turgut's (2013) study differs from prior studies in approaching the factors of board diversity from both dimensions. They classify factors relating to the demographic phenomenon as a diversity-in-boards index, and factors relating to the structural phenomenon as a diversity-of-boards index.

Although such stakeholder scrutiny is much stronger in developed nations, recent empirical studies have shown an increasing trend of corporate social responsibility disclosure in developing countries (Haji 2013). Despite this welcome trend, studies in both developed and developing countries have mainly focused on disclosure quantity (Ho and Wong 2001, Xiao and Yuan 2007), and a limited number of empirical studies have investigated disclosure quality (Haji 2013). To combine disclosure quantity and disclosure quality, this study measures corporate social disclosure (CSD) using three dimensions which combine disclosure quantity and two aspects of disclosure quality from the stakeholder perspective: the quality of the items disclosed and the quality of the types of disclosure about CSD, as perceived by stakeholders.

This investigation is especially pertinent to developing countries, where the understanding of CSD practices is still poor because such practices are perceived as philanthropic activities. Bui (2010) also shows that in the past Vietnamese firms have paid little attention to CSD for three main reasons: the firms do not understand disclosure impacts on society, and lack both 
financial resources and an enforcing legal framework. These factors have discouraged firms from adopting CSD in their corporate policies. While international economic integration has helped Vietnamese businesses to expand their activities globally, they have been also facing important issues for sustainable development, especially relating to society and the environment. Recent scandals concerning serious factory-generated pollution of the Thi-Vai river and various health safety cases such as tainted milk distribution, toxic ingredients in consumer goods, and pesticide residue in vegetables have resulted in a greater concern for social responsibility in Vietnam. Along with these environmental and health issues, Vietnamese export companies have been also encountering issues relating to certification and standards when their foreign investors and buyers require them to adopt business practices based on respect for people, communities and the environment. For example, the U.S.Vietnam textiles agreement of 2003 included an obligation for the Vietnamese authorities to encourage exporting companies to implement corporate social responsibility codes in the U.S. and disclose about them in return for access to the U.S. market. Additionally, Vietnam's tenyear Socio-Economic Development Plan (2011-2020) shows the beginnings of a policy focus on structural reforms, environmental sustainability, social equity, and macro-economic stability (World Bank 2015).

It is proposed that board diversity can help challenge management to show responsibility beyond shareholders (CIMA 2011). This is pertinent to a country such as Vietnam, as explosive economic growth propelled by Vietnamese firms can also bring social problems. In spite of an increasing awareness of CSD among Vietnamese firms recently, there has not been any research that has examined the effect of board diversity on CSD in Vietnamese listed firms.

As adopted by Strand (1983), corporate social performance refers to a firm's anticipated or existing social demands, and corporate social disclosures are disclosures about these demands. Importantly, this study does not equate CSD with social performance, the locus of a 
great debate in the literature (Ullmann 1985). We focus here on CSD in annual reports rather than on social performance because CSD, similar to earnings, is easily spotted (Yip et al., 2011). Annual reports are the main public document and are regularly produced to communicate corporate review, whereas measuring social performance, especially in developing countries like Vietnam, is difficult because there is no database from which to elicit information about such performance. In addition, in the absence of formalized social performance information in databases, and given that measuring social performance requires measuring from several dimensions, manual measurement can lead to higher margins of error (Yip et al. 2011).

\section{Literature review}

Recent research has shown that CSD brings firms greater utility. Cheng, Ioannou and Serafeim (2014) and Ioannou and Serafeim (2015) find that firms with better CSD have lower capital constraints and better access to finance. Dhaliwal et al. (2011) show that firms experience a decrease in cost of equity capital after issuing a CSR report. Dhaliwal et al. (2012) find that the issuance of stand-alone CSR reports is associated with lower analyst forecast error. Brammer and Pavelin (2008) document that environmental disclosure eases legislative pressures and brings economic benefits in the future (Matsumura et al. 2014).

A large number of studies on the relationship between corporate governance and corporate disclosure have been done around the world. For example, Chen and Jaggi (2000) find a positive relation between board independence and voluntary disclosure of Hong Kong listed firms. In contrast, in Singapore, Eng and Mak (2003) find that an increase in outside directors decreases corporate disclosure. Unlike these findings, Matolcsy et al. (2012) show that there is no association between board composition and certain types of disclosure of Australian Stock Exchange listed firms. The mixed findings of studies show that country-specific factors may moderate the association between corporate governance and corporate disclosure. 
Previous studies have also mainly examined the effect of isolated factors concerning the structure of the board of directors, on corporate social responsibility or corporate social performance (Haniffa and Cooke 2005, Naser et al. 2006, Prado-Lorenzo et al. 2009), and have produced mixed findings. Some studies find that independent directors are positively related to corporate social responsibility disclosure (Lattemann et al. 2009, Webb 2004). Others find a negative relationship (Haniffa and Cooke 2005). Still others find no association (Cormier et al. 2011, Michelon and Parbonetti 2012). Another feature of prior studies is that they primarily investigate factors to do with the board of directors' demographic dimensions in isolation. In particular, they have been mainly about gender diversity impacting on corporate social responsibility disclosure. Corporate social responsibility or corporate social performance in these studies is measured based on the available databases such as the FTSE4 Good Global Index, KLD, KEJI Index, and SiRi Pro ${ }^{\mathrm{TM}}$. These studies however bring important revelations. For instance, they show that female directors positively influence charitable giving (Wang and Coffey 1992, Williams 2003), as well as safe and healthy work environments (Bernardi et al. 2006, Johnson and Greening 1999).

In this context, Hafsi and Turgut (2013) make a vital contribution to understanding board diversity. Examining the influence of board diversity from two dimensions on the social performance of firms listed on S\&P 500, they discover that diversity-in-boards is statistically significant and positively related to social performance, and that diversity-of-boards does not significantly influence social performance.

There is only one study ( $\mathrm{Vu}$ et al. 2011) that has investigated the influence of corporate governance on voluntary disclosures, including social disclosure, in Vietnam. Looking at 45 Vietnamese listed firms in 2008, that study uses the percentage of independent directors as a proxy measure for corporate governance, and measures the disclosure quantity. Controlling for the influence that ownership structure can have on voluntary disclosures, Vu et al. (2011) find low disclosure levels among Vietnamese listed firms. They also find that state ownership 
in firms negatively influences social disclosure, but managerial ownership positively influences disclosure. Additionally, larger firms are positively associated with voluntary disclosure.

This study embraces the dichotomous classification of the diversity of the board of directors adopted by Hafsi and Turgut (2013). However, this study contextualizes the attributes of diversity-in-boards and diversity-of-boards to Vietnam, an emerging market. This is done on the basis that prior research concludes that governance structures probably develop endogeneity depending on firm-specific characteristics and the unique business environment in a particular country (Demirguc-Kunt et al. 2006, Haniffa and Hudaib 2006, Love 2011). Further, this study first assumes that attributes of board diversity are of equal importance (unweighted method), and then assigns unequal importance to measure diversity-in-boards and diversity-of-boards indices. The weights are based on the responses received from a survey questionnaire answered by listed firms' executives on the relative importance of these attributes in relation to CSD. A comparison of results between these two measurement methods (weighted and unweighted) allows this study to investigate the potential impact of the perceived importance of attributes relating to the diversity-in-boards and diversity-ofboards and their relationship with CSD. Therefore, this study extends Hafsi and Turgut's (2013) and $\mathrm{Vu}$ et al.'s (2011) studies while examining the influence of board diversity on CSD in Vietnam.

\section{Theoretical framework}

Resource dependence theory and agency theory are two organizational theories that underpin how board diversity influences CSD (Bear et al. 2010). Although Bear et al. (2010) use these theories to investigate the impact of board diversity on corporate social responsibility ratings, not disclosure, prior studies show a link between corporate social responsibility ratings and disclosure. For example, Gelb and Strawser (2001) find that firms with higher corporate social responsibility ratings provide more extensive disclosures, suggesting that corporate 
social responsibility reports published by firms reflect corporate social responsibility performance. Similarly, Dhaliwal et al. (2011) also show that firms with better corporate social responsibility performance are more likely to disclose their corporate social responsibility activities to the market.

Board diversity is presented as both fiduciary and advisory in nature. These roles may affect CSD differently. From the fiduciary perspective, agency theory offers an intention of the board of directors to monitor managerial actions affecting shareholders (Fama and Jensen 1983). This monitoring role ensures that the interest of managers aligns with that of shareholders, including minority shareholders (Fama 1980, Fama and Jensen 1983). The key aim of the board of directors' fiduciary duty is to minimize agency costs. Since monitoring is a fiduciary function of the board, how effectively a board monitors whether managers act to serve their self-interest rather than the interests of the shareholders they represent can differ between boards.

From the advisory perspective of governance, the diversity among board members within a firm is a resource firms depend on for good governance (Pfeffer and Salancik 1978). Resource dependence theory shows that improving social relationships is likely to result in economic returns for a firm (Hafsi and Turgut 2013). Resource dependence theory suggests that the board of directors is a resource for a firm, comprising expertise, advice, reputation, and information networks that the directors bring to the firm (Hillman and Dalziel 2003). Diversity among board members can engage responsibility towards society as well as towards shareholders, as some directors can introduce values such as economic development being concomitant with moral development (Boyd 1990, Labelle et al. 2010).

\subsection{Research hypotheses}

The structural attributes of the board are vital to corporate governance practices (Haniffa and Cooke 2002) and can influence the disclosures made in annual reports of the firm (Haniffa and Cooke 2005). Using the proposition of agency theory, the structural attributes of a board 
can offer a guarantee that the board will fulfill its fiduciary function by aligning firms goals with the stakeholder interests (Fama and Jensen 1983, Haniffa and Cooke 2005). Such alignment can enhance reporting transparency and can lead to high-quality dissemination of social information. Based on this perspective, the following hypothesis is proposed:

\section{Hypothesis 1: Higher diversity-of-boards leads to higher CSD.}

Prior studies mostly find a positive relationship between women in the boardroom and social performance (e.g., Boulouta 2013, Williams 2003) or social disclosure (e.g., Galbreath 2011). Hafsi and Turgut (2013) find that diversity-in-boards significantly and positively associates with social performance. Using the proposition of resource dependence theory, diversity among directors in a firm is a necessary resource for a firm to realize and respond to the impact of its activities on the environment (Boyd 1990). That realization can assist the firm in addressing CSD issues and adopting appropriate disclosure practices. In line with prior findings and resource dependence theory, this research argues that diversity-in-boards leads to CSD relevant to stakeholders. The following hypothesis is therefore stated.

\section{Hypothesis 2: Higher diversity-in-boards leads to higher CSD.}

\section{Methodology}

\subsection{Measuring CSD}

Content analysis has been used extensively in examining firms' voluntary disclosure (Abeysekera and Guthrie 2005, Haniffa and Cooke 2005), and is used in this study to examine the extent of CSD in annual reports.

In analyzing the annual report content of Vietnamese firms, one author coded all the annual reports for the social information to ensure consistent and valid data collection. This was repeated after two weeks by the same author (Haji 2013, Weetman and Ghazali 2006) to establish intra-rater reliability. As a second step to establish inter-rater reliability, another author coded ten randomly selected annual reports and found no significant difference between the two coders. It should be noted that reliability of content analysis can be achieved 
through having multiple coders, or alternatively by having a single coder assign the scores and then take some additional time to review the assigned scores (Neuendorf, 2002, Haji 2013). Additionally, Milne and Adler (1999) explain that there are several different ways to measure reliability, and there is no single criterion of adequate reliability within any of these methods.

This study uses the social indicators section in the Global Reporting Initiative (GRI) 3.1 framework to measure CSD. The framework is versatile across firms and geographies. Currently, the GRI framework is extensively used to assess and measure Sustainability Reporting, including CSD (Hopkins 2012). The social indicators in the GRI 3.1 index are classified into four vital performance aspects: product responsibility, society, human rights, and labor practices. The items in the index include 15 labor practices indicators (LA1 to LA15), 11 human rights indicators (HR1 to HR11), 10 society indicators (SO1 to SO10), and 9 product responsibility indicators (PR1 to PR9). These GRI framework items are used to obtain information about CSD from annual reports (Adams 2002).

\subsection{Measuring disclosure quantity}

This study measures disclosure quantity, by assigning " 1 " if an item is present in the annual report, otherwise zero. This binary coding is consistent with CSD studies of firms in emerging nations (Haji 2013, Haniffa and Cooke 2005, Khan et al. 2013).

\subsection{Measuring disclosed item quality and disclosed type quality}

Using the binary approach to measure disclosure quantity has been criticized for assuming all disclosure items are equally important (Barako et al. 2006). Lu and Abeysekera (2014) overcome that assumption by combining the importance of disclosure items and the importance of disclosure types into disclosure quantity, in examining social and environmental disclosure. They ascertain the importance of disclosure items (i.e., disclosed item quality) and disclosure types (i.e., disclosed type quality) by questioning 12 stakeholders, and assign weights accordingly. Following the approach initiated by $\mathrm{Lu}$ and Abeysekera 
(2014), this study obtains perceptions from 652 stakeholders about the importance of disclosed items.

This study conducts a survey of stakeholders to obtain their perspectives on disclosure type preference (i.e., monetary quantification, numerical quantification, narrative, or both monetary and numerical) (Guthrie and Parker 1990), and the importance of reporting items (i.e., items in the social indicators of GRI 3.1). If the same item is disclosed more than once with different types, an average score is computed to allow each item to contribute once to the overall results.

This study prepared four different questionnaire versions for four different stakeholder groups, and the questionnaires were hand delivered to respondents. The employee questionnaire (labor stakeholders) asked about labor practices. The customer questionnaire (product stakeholders) invited responses on aspects of product responsibility. The local communities questionnaire (society stakeholders) asked members of local communities about societal aspects. The social equity questionnaire asked lawyers and regulators (human rights stakeholders) to respond about human rights aspects. These groups of users were selected based on their likely differences of interest on social issues, aligning with the range of expectations set out in the GRI 3.1, as follows. The product responsibility indicators address the aspects of a reporting organization's products and services that directly affect customers. The society indicators focus attention on the impact that organizations have on local communities. Labor practices indicators act as a dialogue between the company and its employees, and the degree to which employees are organized in representative bodies. Human rights indicators require organizations to report on the extent to which processes have been implemented, on incidents of human rights violations, and on changes in the stakeholders' ability to enjoy and exercise their human rights during the reporting period. Lawyers and regulators were included to encompass this aspect. 
The literature notes that shareholders are considered one of the most important stakeholder groups regarding CSD (Aerts et al. 2007, 2008, Berthelot et al. 2012, Clarkson et al. 2013, Cormier et al. 2011, Dhaliwal et al. 2011, Dhaliwal et al. 2012, Ioannou \& Serafeim 2014). The four stakeholder groups selected for the survey, however, did not include shareholders, consistent with the GRI 3.1 framework adopted in this study where shareholder interest is not separately identified but is posited to be in all stakeholder groups.

The questionnaire used in the study has a scale of zero (unimportant) to 10 (the most important), making it an 11-point scale. A wide scale increases the variance of responses obtained and makes the results more reliable (Dawes 2002, Hartley and Betts 2010). The stakeholder-specific groups were requested to rate each item from zero to 10 based on their perceptions of how important the item was to them and how the items should be disclosed. In relation to how an item should be disclosed, they evaluated four disclosure types (i.e., narrative, monetary quantification, numerical quantification, both monetary and numerical) for each item using a zero-to-10 rating scale.

The weight for a particular item is computed by the total of the integer values assigned to the item and then divided by the number of individuals who responded to the item. Similarly, the level of importance for each type (i.e., narrative, monetary quantification, numerical quantification, both monetary and numerical) of a particular item is calculated by the total of the integer values assigned to each particular type of disclosure for each item and then divided by the number of respondents for this type. A mean score is used to summarize the response scores within a specific stakeholder group.

\subsection{The stakeholder-driven, three-dimensional CSD index}

The CSD in this research is driven by stakeholders and has three dimensions. The three dimensions are combined to develop a CSD index. The CSD index of a firm is computed according to the following equation: 


$$
C S D_{j}=\frac{\sum_{i=1}^{n} \text { Quantity }_{i} \text { xItemQuality }_{i} x \text { TypeQuality }_{i}}{\max \left(\text { SCORE }_{i}\right)}
$$

where $C S D_{j}=$ a stakeholder-driven, three-dimensional index of firm $j$; Quantity $y_{i}=$ the disclosure or non-disclosure of an item $i$ with regard to this item's disclosure type in firm $j$; ItemQuality $_{i}=$ the weight of the item $i$ disclosed; TypeQuality ${ }_{i}=$ the weight for the type (i.e., narrative, monetary quantification, numerical quantification, or both monetary and numerical) of the item $i$ disclosed; $n=$ the number of items within the checklist; $\max (\mathrm{SCORE})=$ the highest score of three disclosed dimensions for a specified firm: disclosed quantity score $\mathrm{x}$ disclosed item quality score $\mathrm{x}$ disclosed type quality score.

\subsection{Measures of board diversity}

Four board diversity indices are constructed to measure board diversity: an unweighted diversity-of-boards index (UW_DoB), an unweighted diversity-in-boards index (UW_DiB), a weighted diversity-of-boards index (W_DoB), and a weighted diversity-in-boards index (W_DiB).

The unweighted board diversity indices (UW_DoB and UW_DiB) are constructed based on the guidance provided by Hafsi and Turgut (2013). The diversity indices combine several attributes of the board either relating to the structure (DOB) or relating to directors in the board (DIB), with equal weights assigned to them. Since assigning equal importance to each attribute is hypothetical (Ben-Amar et al. 2013), this study constructs two additional board diversity indices that are weighted (W_DoB and W_DiB). The weights are based on the responses received from a survey questionnaire answered by listed firms' executives.

\subsubsection{Unweighted diversity-of-boards index}

This study includes four structural attributes relating to the board, to construct the diversityof-boards indices. Table 1 describes these measures.

Table 1. Description and composition of independent variables (diversity indices).

\begin{tabular}{ll}
\hline Variables & Measurement \\
\hline Independent variables: diversity-of-boards indices \\
$\mathrm{CEO} /$ chair separation & 0 if the chairperson also serves as the CEO and 1 otherwise.
\end{tabular}


Non-executive directors owning 1 if there is more than one non-executive director who also more than $5 \%$ of a firm's equity serves as a blockholder and 0 otherwise.

(blockholders)

Representative directors' ownership The percentage of state ownership represented by directors.

Promoters

The number of inside directors also serving as representative directors for government divided by the number of directors.

Independent variables: diversity-in-boards indices

Director gender

Using modified Blau's index with a classification of male and female directors.

Director age

Using modified Blau's index with a classification of five subgroupings: under 36 years, 36-45, 46-55, 56-65, and over 65 .

Director education degree

Using modified Blau's index with a classification of four subgroupings: $\mathrm{PhD}$, master's, bachelor's and others.

Director nationality

Using modified Blau's index with a classification of foreign and domestic directors.

This study constructs UW_DoB using the cluster analysis method (Han and Kamber 2006) as employed in previous studies (Deza and Deza 2009, Hafsi and Turgut 2013). This measurement represents dissimilarity among firm boards using the structural attributes of the board, and shows the extent to which all four structural attributes of the board in a given firm board are dissimilar from those of other firm boards in the sample.

Three main steps are used to ascertain the extent to which a board is dissimilar from the remaining boards. First, a matrix is developed by measuring the dissimilarity between a given firm and other firms, for each structural attribute of the board. Second, the extent of dissimilarity between a given firm and the other firms on all structural attributes (i.e., four attributes in this study) of the board is calculated. Third, the average dissimilarity between a given firm and the remaining firms in the sample is generated. This becomes the UW_DoB of the given firm.

The structural attributes of boards in this study contain binary and ratio scale data types. Han and Kamber (2006) have shown how to measure inter-sample differences with different data types, and their approach is accordingly used here to quantify the inter-sample differences. This method lumps together several attributes in a single dissimilarity matrix and uses a standardized range with differences from 0 to 1 for all the attributes. Each attribute in a given firm is measured and compared to the same attribute in the remaining firms in the 
sample. If the measurement value is different, then that attribute value is recorded as different, and receives a score of more than zero; otherwise it is zero. Each attribute in a given firm is compared in this way. A higher scale represents higher diversity-of-boards. The details of this method are given in the Appendix.

\subsubsection{Unweighted diversity-in-boards index}

Table 2 describes the measurement of four demographic attributes of the board of directors to illustrate how demographic attributes are diverse among directors within a board representing a firm (gender, age, educational qualifications, and nationality). Each of these attributes is first measured using Blau's index (1977). Blau's index is recommended as an optimal method to measure dissimilarities within a group (Harrison and Klein 2007). This index is computed as follows:

$$
1-\sum\left(p_{n}^{2}\right)
$$

where $\mathrm{n}=1, \ldots, \mathrm{N}$ possible categories, and $\mathrm{p}$ is the percentage of members of the board of directors in the $\mathrm{n}^{\text {th }}$ category. When Blau's index gains a large value, diversity-in-boards increases. However, in order to obtain a standardized range from zero to unity for all demographic diversity attributes, the method introduced by Agresti and Agresti (1978) is used. In this method, Blau's index is multiplied by $\mathrm{N} /(\mathrm{N}-1)$ to create what is termed a modified Blau's index. Then, to construct UW_DiB, the sample is split into terciles for each attribute to rank the levels of diversity (Ben-Amar et al. 2013, Hafsi and Turgut 2013). These groups then take values of 0 for the first tercile, 1 for the second, and 2 for the third. Finally, UW_DiB is the sum of all the ranked attributes that are involved in the demographic diversity within a board for each firm, such that a higher value represents a higher diversity-in-boards.

\subsubsection{Weighted diversity-of-boards and weighted diversity-in-boards indices}


This study constructs a weighted diversity-of-boards index (W_DoB) and weighted diversityin-boards index (W_DiB) similar to UW_DoB and UW_DiB, using each attribute relating to the board structure and to directors within a board. These attributes are weighted based on executives' perceptions on their relative importance (Dess and Davis 1984, Van der Walt et al. 2006). ${ }^{3}$ The corporate executives of Vietnamese listed firms have an experiential understanding of how keen the directors in a board are to enhance the quality of earnings and CSD. Hence, the survey asked executives to assign a value to each attribute of directors within a board towards impacting on CSD of their firm. Each attribute is assigned a value ranging from zero (unimportant) to 10 (most important). The questionnaire was sent to 150 executives of all the firms in the sample. There were 80 usable responses, representing $53.33 \%$ of the sample.

This study calculates $\delta_{i j}^{(f)}$ in Equation (3) for each attribute to construct a weighted diversity-of-boards index (W_DoB) for each firm using the following formula:

$$
\delta_{i j}^{(f)}=\frac{p^{*} \text { MEANRATING }_{f}}{\sum_{f=1}^{p} \text { MEANRATING }_{f}}
$$

where $\delta_{i j}^{(f)}$ is the indicator of attribute $f$ weighted; $p$ is the number of attributes $\mathrm{f}$; and MEANRATING is the mean importance rating of each attribute $f$ based on executives' perceptions in the survey. Equation (3) is then used with $\delta_{i j}^{(f)}$ modified to measure W_DoB of each firm board.

Each attribute is measured as the mean score from the questionnaire survey. It is then used to measure the weighted diversity-in-boards index (W_DiB) for that firm. The W_DiB is calculated as the sum of all four ranked attributes, and each ranked attribute is multiplied by the mean value of importance rating obtained from the survey. A higher value represents a higher diversity-in-boards in that firm.

\subsection{Control variables}


This study controls for the firm characteristics return on assets (ROA), auditors (AUDIT), state ownership (STATE), foreign ownership (FOREIGN), and stock exchange location (STOCK_EX), which have been shown to influence CSD (Cormier et al. 2011, Purushothaman et al. 2000, Vu et al. 2011, Vu 2012). Although CSD can vary widely across industries (Mahadeo et al. 2011), the study does not control for industry type because the business activities of most Vietnamese listed firms are conducted in multiple industry sectors, and at present there are no norms for distinct industry classifications of listed firms in Vietnam (Nguyen 2012). The description of the control variables is given in Table 5.

\subsection{Empirical models: The effects of board diversity on CSD}

The first and second hypotheses, which examine the impact of board diversity on CSD, are tested using the following two regression functions:

$$
\begin{aligned}
& \mathrm{CSD}_{i}=\alpha_{0}+\alpha_{1} \mathrm{DoB}_{i}+\sum \gamma_{j, i} \text { control variables }_{i}+\varepsilon_{i} \\
& \mathrm{CSD}_{i}=\beta_{0}+\beta_{1} \text { DiB }_{i}+\sum \eta_{j, i} \text { control variables }_{i}+\varepsilon_{i}
\end{aligned}
$$

where $\mathrm{CSD}_{\mathrm{i}}=$ firm $i$ 's stakeholder-driven, three-dimensional CSD index; $D o B_{i}=$ firm i's indices of diversity-of-boards; $D i B_{i}=$ firm i's indices of diversity-in-boards; $i=1, \ldots, n$ firms.

\subsection{The sample}

This study examines the 2010 annual reports to capture the quantity and quality of CSD of Vietnamese listed firms. The 2010 year was chosen in this study because on 15 January 2010, the Ministry of Finance in Vietnam issued the Circular 09/2010/TT-BT Guidance for Information Disclosure on Stock Exchange with the aim of providing guidance to enhance the disclosure practices of Vietnamese listed firms. The results of this study can help the Ministry of Finance form a better understanding of listed firms' CSD practices to revise and upgrade this Circular for guidance on CSD. The sample was based on the 150 firms listed on the Ho Chi Minh stock exchange (HOSE) and Hanoi stock exchange (HNX) in 2010 that had been listed for the three-year period from 2008 to 2010, and that were not banks or financial 
institutions. The three-year criterion was adopted in this study to avoid newly listed firms as these firms may be less representative in terms of CSD (Lim et al. 2007). The necessary data for board diversity, CSD, and information about control variables was hand-collected from the 2010 annual reports. Because annual reports proved were not to be available for 17 of those firms, the final sample contained 133 firms.

The annual reports were retrieved from HOSE and HNX websites as well as firm websites. Firms in the finance sector operate under a tight regulatory environment and are subject to various other disclosure requirements. Several previous CSR studies have excluded finance firms when analyzing non-finance firms (Haji 2013, Haniffa and Cooke 2005). Hence, banks and financial institutions are excluded.

\section{Results}

Table 2 shows the response rate to the different versions of the questionnaire; the average response rate was $60 \%$.

Table 2. Response rate of target groups.

\begin{tabular}{lccc}
\hline Respondents & $\begin{array}{c}\text { Distributed } \\
\text { questionnaires }\end{array}$ & $\begin{array}{c}\text { Completed } \\
\text { questionnaires }\end{array}$ & $\begin{array}{c}\text { Response } \\
\text { rate (\%) }\end{array}$ \\
\hline Local communities (society aspects) & 350 & 243 & 69.43 \\
Customers (product aspects) & 270 & 158 & 58.52 \\
Employees (labor aspects) & 270 & 164 & 60.74 \\
Lawyers and regulators (human rights aspects) & 190 & 87 & 45.79 \\
\hline Total & 1080 & 652 & 60.37 \\
\hline
\end{tabular}

Table 3 shows the score distribution of 80 executives' perceptions regarding the attributes of board diversity. The mean scores vary between 5.13 (gender diversity) and 7.93 (nationality diversity), with the lowest being zero and the highest being 10 .

Table 3. Descriptive statistics for the importance rating based on executives' perspectives about the board of directors' attributes in relation to CSD.

\begin{tabular}{lcccc}
\hline \multicolumn{1}{c}{ Importance rating } & Max & Min & Mean & SD \\
\hline Structural attributes & & & & \\
CEO/chair separation & 10 & 5 & 7.53 & 1.73 \\
\% Representative directors' ownership & 9 & 5 & 7.13 & 1.25 \\
\% Promoters & 10 & 3 & 6.47 & 1.85 \\
Non-executive directors owning > 5\% of a firm's equity & 9 & 0 & 6.33 & 2.44 \\
\hline Demographic attributes & & & & \\
Gender diversity & 8 & 0 & 5.13 & 2.36 \\
Age diversity & 8 & 0 & 5.87 & 2.29 \\
Educational qualifications diversity & 10 & 5 & 7.60 & 1.35
\end{tabular}




\subsection{Labor aspect (LA)}

Panel A of Table 4 shows the ratings awarded by employees to the various reporting items concerning the labor aspect (LA). The highest mean score for those reporting items is 7.47 and the lowest is 6.44 , out of a maximum possible score of 10 (column 2). In analyzing the disclosure types (columns 3 to 6 ) for the 15 reporting items (LA1 to LA15) for the labor aspect, employee respondents rated the highest scores, which are printed in bold in the Table, for items with numerical disclosures (9 items), i.e., LA2, LA3, LA15, LA4, LA5, LA7, LA9, LA13, and LA14, and for the reporting items with both monetary and numerical disclosures (6 items), i.e., LA1, LA6, LA8, LA10, LA11, and LA12. Meanwhile, the lowest scores, printed in italics in the table, were given to the items with monetary disclosures (11 items), i.e., LA2, LA3, LA15, LA4, LA5, LA7, LA8, LA9, LA12, LA13, and LA14, and the items with narrative disclosures (4 items), i.e., LA1, LA6, LA10, and LA11.

\subsection{Human rights (HR) aspect}

Table 4, Panel B, provides the ratings awarded by lawyers and regulators for the various information items on the human rights aspect (HR). The highest mean score for the information items is 8.19 and the lowest is 6.38 (column 2). Relating to the disclosure types (columns 3 to 6), out of 11 items (HR1 to HR11) in the human rights aspect, lawyers and regulators assigned the highest scores to the items with numerical disclosures ( 9 items), and to the items with both monetary and numerical disclosures ( 2 items). The items with narrative disclosures (10 items) and the items with monetary disclosures (1 item) received the lowest scores.

\subsection{Societal (SO) aspect}

Table 4, Panel $\mathrm{C}$, presents the ratings assigned by the members of local communities to the various reporting items concerning the societal aspect (SO). The highest mean score for the reporting items is 7.92 and the lowest is 6.22 (column 2). Relating to the disclosure types 
(columns 3 to 6), out of 10 items (SO1 to SO10) in the societal aspect, local communities assigned the highest scores for all 10 items with both monetary and numerical disclosures. They assigned the lowest mean scores scores to all 10 items with narrative disclosures.

\subsection{Product (PR) aspect}

Table 4, Panel D, shows the ratings awarded by customers for the various reporting items about the product aspect (PR). The highest mean score for the reporting items is 8.08 and the lowest is 6.62 (column 2). Relating to the disclosure types (columns 3 to 6), out of 9 items (PR1 to PR9) in the product aspect, customers assigned the highest scores for items with both monetary and numerical disclosures (8 items), and one item with narrative disclosure. They assigned the lowest scores to the items with narrative disclosures (5 items), monetary disclosures (3 items), and one item with numerical disclosure.

Table 4. List of 45 items with the mean importance weighted by four stakeholderspecific groups for disclosure items and types, in order of relative importance.

Panel A: List of 15 labor items and the mean importance weighted by employees for disclosure items and types.

\begin{tabular}{lccccc}
\hline \multirow{2}{*}{$\begin{array}{l}\text { Labor items } \\
(\text { LA })\end{array}$} & \multirow{2}{*}{$\begin{array}{c}\text { Mean weight of } \\
\text { items disclosed }\end{array}$} & \multicolumn{4}{c}{ Mean weight of each type of disclosure } \\
\cline { 3 - 6 }$(1)$ & $(2)$ & $(3)$ & $(4)$ & $(5)$ & $(6)$ \\
\hline LA11 & $\mathbf{7 . 4 7}$ & 6.53 & 6.75 & 6.92 & $\mathbf{7 . 5 1}$ \\
LA7 & 7.38 & 6.28 & 6.00 & $\mathbf{7 . 1 7}$ & 7.06 \\
LA8 & 7.29 & 6.49 & 6.31 & $\mathbf{7 . 0 2}$ & 6.97 \\
LA4 & 7.28 & 6.22 & 5.99 & $\mathbf{7 . 1 9}$ & 6.92 \\
LA5 & 7.28 & 6.34 & 5.99 & $\mathbf{7 . 0 9}$ & 6.84 \\
LA9 & 7.27 & 6.54 & 6.37 & $\mathbf{7 . 0 6}$ & 6.88 \\
LA3 & 7.18 & 6.15 & 7.00 & 7.19 & $\mathbf{7 . 6 8}$ \\
LA2 & 7.15 & 6.03 & 5.85 & $\mathbf{6 . 9 2}$ & 6.69 \\
LA12 & 7.11 & 6.65 & 6.10 & 7.10 & $\mathbf{7 . 1 2}$ \\
LA10 & 7.05 & 6.20 & 6.02 & $\mathbf{6 . 9 4}$ & 6.90 \\
LA1 & 6.97 & 5.77 & 5.85 & 7.04 & $\mathbf{7 . 2 7}$ \\
LA14 & 6.78 & 5.84 & 6.35 & 6.74 & $\mathbf{7 . 1 6}$ \\
LA15 & 6.7 & 5.73 & 5.69 & 6.88 & $\mathbf{6 . 9 0}$ \\
LA6 & 6.47 & 5.94 & 5.60 & $\mathbf{6 . 6 9}$ & 6.34 \\
LA13 & 6.44 & 5.97 & 5.27 & $\mathbf{6 . 5 3}$ & 6.26 \\
\hline
\end{tabular}

Panel B: List of 11 human right items and the mean importance weighted by lawyers and regulators for disclosure items and types

\begin{tabular}{|c|c|c|c|c|c|}
\hline \multirow{2}{*}{$\begin{array}{l}\text { Human rights } \\
\text { items (HR) }\end{array}$} & \multirow{2}{*}{$\begin{array}{l}\text { Mean weight } \\
\text { of items } \\
\text { disclosed }\end{array}$} & \multicolumn{4}{|c|}{ Mean weight of each type of disclosure } \\
\hline & & Narrative & Monetary & Numerical & $\begin{array}{c}\text { Both monetary and } \\
\text { numerical }\end{array}$ \\
\hline
\end{tabular}




\begin{tabular}{lccccc}
\cline { 3 - 6 }$(1)$ & $(2)$ & $(3)$ & $(4)$ & $(5)$ & $(6)$ \\
\hline HR7 & $\mathbf{8 . 1 9}$ & 5.27 & 5.90 & $\mathbf{7 . 9 0}$ & 6.64 \\
HR11 & 7.98 & 5.19 & 6.00 & $\mathbf{7 . 5 2}$ & 7.36 \\
HR4 & 7.9 & 5.28 & 5.25 & $\mathbf{7 . 6 4}$ & 6.78 \\
HR6 & 7.89 & 5.43 & 6.07 & $\mathbf{7 . 8 9}$ & 7.21 \\
HR5 & 7.28 & 4.91 & 5.23 & $\mathbf{6 . 9 9}$ & 6.32 \\
HK9 & 7.19 & 5.26 & 5.62 & $\mathbf{6 . 7 9}$ & 6.61 \\
HR3 & 7.18 & 4.62 & 5.64 & $\mathbf{7 . 0 3}$ & 6.82 \\
HR8 & 6.93 & 5.53 & 5.83 & $\mathbf{6 . 9 6}$ & 6.53 \\
HR10 & 6.71 & 4.87 & 5.17 & $\mathbf{6 . 4 5}$ & 6.41 \\
HR1 & 6.69 & 4.71 & 6.01 & 7.05 & $\mathbf{7 . 6 8}$ \\
HR2 & 6.38 & 4.55 & 5.30 & 6.75 & $\mathbf{6 . 9 7}$ \\
\hline
\end{tabular}

Panel C: List of 10 society items and the mean importance weighted by local communities for disclosure items and types

\begin{tabular}{lccccc}
\hline $\begin{array}{l}\text { Society items } \\
\text { (SO) }\end{array}$ & $\begin{array}{c}\text { Mean weight of } \\
\text { items disclosed }\end{array}$ & Narrative & Monetary & Numerical & $\begin{array}{c}\text { Both monetary } \\
\text { and numerical }\end{array}$ \\
\cline { 3 - 6 }$(1)$ & $(2)$ & $(3)$ & $(4)$ & $(5)$ & $(6)$ \\
\hline SO2 & $\mathbf{7 . 9 2}$ & 4.91 & 6.35 & 6.50 & $\mathbf{7 . 5 8}$ \\
SO8 & 7.81 & 5.49 & 6.98 & 6.99 & $\mathbf{7 . 9 0}$ \\
SO1 & 7.67 & 4.61 & 6.53 & 6.04 & $\mathbf{7 . 9 7}$ \\
SO10 & 7.52 & 5.06 & 5.87 & 6.22 & $\mathbf{7 . 4 3}$ \\
SO4 & 7.41 & 5.11 & 6.10 & 6.55 & $\mathbf{7 . 5 5}$ \\
SO7 & 7.35 & 5.45 & 6.12 & 6.36 & $\mathbf{7 . 3 8}$ \\
SO9 & 7.26 & 4.79 & 5.58 & 6.09 & $\mathbf{7 . 3 2}$ \\
SO3 & 7.24 & 5.06 & 5.74 & 6.57 & $\mathbf{7 . 3 4}$ \\
SO6 & 6.94 & 4.88 & 6.21 & 6.09 & $\mathbf{7 . 3 3}$ \\
SO5 & 6.22 & 4.88 & 5.46 & 5.73 & $\mathbf{6 . 4 4}$ \\
\hline
\end{tabular}

Panel D: List of 9 product items and the mean importance weighted by customers for disclosure items and types

\begin{tabular}{lccrrr}
\hline \multirow{2}{*}{$\begin{array}{l}\text { Product items } \\
(\text { PR) }\end{array}$} & $\begin{array}{l}\text { Mean weight } \\
\text { of items } \\
\text { disclosed }\end{array}$ & \multicolumn{5}{c}{ Mean weight of each type of disclosure } \\
\cline { 3 - 6 } & $(2)$ & $(3)$ & $(4)$ & $(5)$ & \multicolumn{1}{c}{$\begin{array}{l}\text { Both monetary and } \\
\text { numerical }\end{array}$} \\
\hline PR1 & $\mathbf{8 . 0 8}$ & 5.22 & 6.14 & 6.58 & $(6)$ \\
PR5 & 8.07 & 6.30 & 6.17 & 7.08 & $\mathbf{7 . 6 8}$ \\
PR9 & 7.8 & 5.61 & 6.56 & 6.70 & $\mathbf{7 . 7 6}$ \\
PR8 & 7.77 & 5.97 & 6.02 & 6.64 & $\mathbf{7 . 0 9}$ \\
PR3 & 7.71 & 5.88 & 5.43 & 6.09 & $\mathbf{6 . 7 4}$ \\
PR7 & 7.64 & 5.56 & 5.62 & 6.49 & $\mathbf{7 . 3 5}$ \\
PR6 & 6.98 & $\mathbf{6 . 0 5}$ & 5.68 & 5.60 & 5.89 \\
PR2 & 6.94 & 5.57 & 5.63 & 6.21 & $\mathbf{6 . 5 3}$ \\
PR2 & 6.62 & 5.59 & 5.28 & 5.57 & $\mathbf{6 . 1 3}$ \\
\hline
\end{tabular}

\subsection{Descriptive statistics}

Table 5 presents the descriptive statistics for the variables used to analyze the impact of board diversity on CSD in the sample of 133 Vietnamese listed firms. The CSD score 
(CSD_INDEX) ranges from 3 percent to 23 percent with a mean of 10 percent, which reveals that the CSD score of listed firms in the sample is low. This is because CSD practices are relatively new in Vietnam (Vu et al. 2011). Our result is consistent with Vu et al.'s (2011) examination of the quantity of voluntary disclosure, including social disclosure in Vietnam.

UW_DoB has a range between 0.23 and 0.49 , and W_DoB has a range between 0.24 and 0.49. The mean values are 0.30 and 0.31 , respectively. The range for UW_DiB is between zero and seven, and its mean value is 3.00. The range for W_DiB is between zero and 47.19 and its mean value is 18.6. The mean values of UW_DiB and W_DiB indicate that diversityin-boards in the sample is quite low.

Related to the control variables, only 21 (16 percent) of the 133 firms in the sample use the Big Four auditing firms. The mean of ROA is 0.08 , which is similar to the 0.07 found by $\mathrm{Vu}$ et al. (2011) for a sample of 45 Vietnamese listed firms in 2008. The Ho Chi Minh stock exchange includes 90 (68 percent) of the 133 listed firms in the sample. Because foreign ownership is limited to 49 percent in Vietnamese listed firms governed by Vietnamese law, the average percentage of foreign ownership (FOREIGN) in this sample is quite low, 12 percent, with a range of 0 to 49 percent. The average percentage of state ownership (STATE) is 27 percent with a range of 0 to 79.07 percent.

Table 5. Descriptive statistics.

\begin{tabular}{|c|c|c|c|c|c|c|c|}
\hline Variables & Mean & SD & Min & Max & $\mathbf{P 2 5}$ & P50 & P75 \\
\hline \multicolumn{8}{|l|}{ Dependent variables } \\
\hline CSD_INDEX & 0.10 & 0.05 & 0.03 & 0.23 & 0.07 & 0.09 & 0.12 \\
\hline \multicolumn{8}{|c|}{ Dependent variables - Additional analysis } \\
\hline LAD_INDEX & 0.17 & 0.08 & 0.03 & 0.41 & 0.12 & 0.18 & 0.22 \\
\hline SOD_INDEX & 0.04 & 0.05 & 0.00 & 0.23 & 0.00 & 0.04 & 0.07 \\
\hline PRD_INDEX & 0.16 & 0.05 & 0.10 & 0.30 & 0.10 & 0.14 & 0.20 \\
\hline HRD_INDEX & 0.01 & 0.04 & 0.00 & 0.25 & 0.00 & 0.00 & 0.00 \\
\hline \multicolumn{8}{|l|}{ Independent variables } \\
\hline UW_DoB & 0.31 & 0.07 & 0.23 & 0.49 & 0.24 & 0.30 & 0.35 \\
\hline W_DōoB & 0.32 & 0.07 & 0.24 & 0.49 & 0.25 & 0.31 & 0.36 \\
\hline UW_DiB & 2.91 & 1.71 & 0.00 & 7.00 & 2.00 & 3.00 & 4.00 \\
\hline W_DiB & 18.75 & 11.27 & 0.00 & 47.19 & 10.26 & 18.60 & 26.94 \\
\hline \multicolumn{8}{|c|}{ Structural attributes of the board of directors to construct DoB_Index } \\
\hline $\mathrm{CEO} /$ chair separation & 0.62 & 0.49 & 0.00 & 1.00 & 0.00 & 1.00 & 1.00 \\
\hline $\begin{array}{l}\text { \% Representative directors' } \\
\text { ownership }\end{array}$ & 0.22 & 0.23 & 0.00 & 0.85 & 0.00 & 0.19 & 0.40 \\
\hline$\%$ Promoters & 0.13 & 0.20 & 0.00 & 0.86 & 0.00 & 0.00 & 0.20 \\
\hline $\begin{array}{l}\text { Non-executive directors owning }>5 \% \\
\text { of a firm's equity }\end{array}$ & 0.14 & 0.35 & 0.00 & 1.00 & 0.00 & 0.00 & 0.00 \\
\hline
\end{tabular}




\begin{tabular}{lccccccc}
\hline Demographic attributes of the board of directors & measured by & the modified Blau's index to construct DiB_Index \\
Gender diversity & 0.38 & 0.38 & 0.00 & 0.98 & 0.00 & 0.49 & 0.64 \\
Age diversity & 0.64 & 0.20 & 0.00 & 0.92 & 0.59 & 0.70 & 0.80 \\
Educational qualifications diversity & 0.41 & 0.26 & 0.00 & 0.93 & 0.29 & 0.43 & 0.64 \\
Nationality diversity & 0.08 & 0.23 & 0.00 & 1.00 & 0.00 & 0.00 & 0.00 \\
\hline Control variables & & & & & & & \\
AUDIT & 0.16 & 0.37 & 0.00 & 1.00 & 0.00 & 0.00 & 0.00 \\
ROA & 0.08 & 0.08 & -0.17 & 0.39 & 0.03 & 0.07 & 0.11 \\
STOCK_EX & 0.68 & 0.47 & 0.00 & 1.00 & 0.00 & 1.00 & 1.00 \\
FOREIGN & 0.12 & 0.14 & 0.00 & 0.49 & 0.02 & 0.05 & 0.17 \\
STATE & 0.27 & 0.21 & 0.00 & 0.79 & 0.07 & 0.28 & 0.50 \\
\hline
\end{tabular}

The final sample consists of 133 firms listed on HOSE and HNX for 2010. CSD_INDEX = the stakeholderdriven, three-dimensional CSD index; UW_DoB = the unweighted index of diversity-of-boards; W_DoB = the weighted index of diversity-of-boards; UW_DiB $=$ the unweighted index of diversity-in-boards; W_DiB $=$ the weighted index of diversity-in-boards; AUDIT = 1 if firm's auditor is a Big Four and otherwise 0; ROA = net profit over the total assets; STOCK_EX $=1$ if the firms listed on HOSE and 0 for firms listed on HNX; FOREIGN $=$ the percentage of shareholding owned by foreign investors; STATE $=$ the percentage of shareholding owned by the state.

Table 6 shows the pairwise correlations between all combinations of variables. UW_DoB and W_DoB are positively correlated with a coefficient of 0.997 , and UW_DiB is positively correlated with W_DiB $(\mathrm{r}=0.988)$. This study therefore undertakes the task of empirically confirming whether UW_DoB and W_DoB, or UW_DiB and W_DiB, have a similar influence on CSD. As expected, the two measures of UW_DiB and W_DiB are positively correlated with CSD_INDEX (coefficients of 0.264 and 0.258 , respectively), while both UW_DoB and W_DoB show no significant correlations.

Table 6. Pairwise correlations.

\begin{tabular}{|c|c|c|c|c|c|c|c|c|c|c|c|}
\hline & & 1 & 2 & 3 & 4 & 5 & 6 & 7 & 8 & 9 & 10 \\
\hline 1 & CSD_INDEX & 1.000 & & & & & & & & & \\
\hline 2 & UW_DoB & 0.140 & 1.000 & & & & & & & & \\
\hline 3 & W_DoB & 0.147 & 0.997 & 1.000 & & & & & & & \\
\hline 4 & UW_DiB & 0.264 & -0.036 & -0.035 & 1.000 & & & & & & \\
\hline 5 & W_DiB & 0.258 & -0.036 & -0.037 & 0.988 & 1.000 & & & & & \\
\hline 6 & AUDIT & 0.286 & 0.145 & 0.152 & 0.011 & 0.042 & 1.000 & & & & \\
\hline 7 & $\mathrm{ROA}$ & 0.183 & -0.059 & -0.051 & 0.062 & 0.054 & 0.045 & 1.000 & & & \\
\hline 8 & STOCK_EX & 0.344 & 0.078 & 0.077 & 0.199 & 0.201 & 0.167 & 0.108 & 1.000 & & \\
\hline 9 & FOREIGN & 0.187 & -0.049 & -0.051 & 0.204 & 0.238 & 0.221 & 0.450 & 0.365 & 1.000 & \\
\hline & STATE & -0.049 & 0.015 & 0.026 & -0.374 & -0.371 & 0.179 & 0.099 & -0.250 & -0.179 & 1.000 \\
\hline
\end{tabular}

\subsection{Checking for multicollinearity and heteroscedasticity}


This study checks the variance inflation factor (VIF) for the regression analysis and finds that the maximum VIF is 1.59 , which is less than 10 , for all the regression models. Therefore, multicollinearity does not influence the empirical models tested in this study (Gujarati and Porter 2009). To avoid the problem of heteroscedasticity (where observations have variable residual values), robust standard error (White 1980) is employed to investigate the impact of board diversity indices (UW_DoB, W_DoB, UW_DiB, and W_DiB) on CSD (CSD_INDEX).

\subsection{Results of hypothesis tests}

Table 7 provides the findings of the tests of hypotheses 1 and 2 where CSD_INDEX is the dependent variable, and UW_DoB, W_DoB, UW_DiB, and W_DiB are the alternate independent variables. The table shows that both UW_DoB and W_DoB are not related to CSD_INDEX (p-values of 0.318 and 0.298 respectively), which rejects hypothesis 1 .

Meanwhile, the coefficient estimates of both UW_DiB and W_DiB are positive and significant (p-values of 0.010 and 0.014 , respectively), indicating that firms with greater diversity-in-boards have a positive influence on higher CSD, confirming hypothesis 2.

Table 7. Board diversity (unweighted and weighted indices) and CSD.

\begin{tabular}{|c|c|c|c|c|}
\hline & CSD_INDEX & CSD_INDEX & CSD_INDEX & CSD_INDEX \\
\hline UW_DoB & $\begin{array}{r}0.057 \\
(0.318)\end{array}$ & & & \\
\hline W_DoB & & $\begin{array}{r}0.062 \\
(0.298)\end{array}$ & & \\
\hline UW_DiB & & & $\begin{array}{r}0.006^{* * * *} \\
(0.010)\end{array}$ & \\
\hline W_DiB & & & & $\begin{array}{r}0.001 * * \\
(0.014)\end{array}$ \\
\hline AUDIT & $\begin{array}{r}0.030 * * \\
(0.013)\end{array}$ & $\begin{array}{r}0.030 * * \\
(0.013)\end{array}$ & $\begin{array}{r}0.030^{* * * *} \\
(0.004)\end{array}$ & $\begin{array}{r}0.030 * * * \\
(0.005)\end{array}$ \\
\hline ROA & $\begin{array}{r}0.101 * * \\
(0.023)\end{array}$ & $\begin{array}{r}0.100 * * \\
(0.023)\end{array}$ & $\begin{array}{c}0.093 * \\
(0.072)\end{array}$ & $\begin{array}{c}0.097 * \\
(0.062)\end{array}$ \\
\hline STOCK_EX & $\begin{array}{r}0.028 * * * \\
(0.000)\end{array}$ & $\begin{array}{r}0.028 * * * \\
(0.000)\end{array}$ & $\begin{array}{r}0.027 * * * \\
(0.002)\end{array}$ & $\begin{array}{r}0.027 * * * \\
(0.001)\end{array}$ \\
\hline FOREIGN & $\begin{array}{r}-0.017 \\
(0.605)\end{array}$ & $\begin{array}{l}-0.017 \\
(0.612)\end{array}$ & $\begin{array}{l}-0.026 \\
(0.400)\end{array}$ & $\begin{array}{r}-0.029 \\
(0.352)\end{array}$ \\
\hline STATE & $\begin{array}{r}-0.010 \\
(0.568)\end{array}$ & $\begin{array}{r}-0.011 \\
(0.563)\end{array}$ & $\begin{array}{r}0.006 \\
(0.742)\end{array}$ & $\begin{array}{r}0.005 \\
(0.786)\end{array}$ \\
\hline Constant & $\begin{array}{r}0.056^{* * * *} \\
(0.002)\end{array}$ & $\begin{array}{r}0.054 * * * \\
(0.005)\end{array}$ & $\begin{array}{r}0.054 * * * \\
(0.000)\end{array}$ & $\begin{array}{r}0.055 * * * \\
(0.000)\end{array}$ \\
\hline $\mathrm{R}^{2}$ & 0.204 & 0.205 & 0.238 & 0.233 \\
\hline Adj- $R^{2}$ & 0.166 & 0.167 & 0.201 & 0.197 \\
\hline F statistic & $6.29 * * *$ & $6.33^{* * *}$ & $6.82 * * *$ & $6.76^{* * *}$ \\
\hline p-value & 0.000 & 0.000 & 0.000 & 0.000 \\
\hline
\end{tabular}


The p-values are in parentheses, calculated using standard errors corrected for heteroscedasticity. Statistical significance is indicated by $* * *, * *$, and $*$ for $1 \%, 5 \%$, and $10 \%$. Please see note below Table 5 for description of each variable.

The results for the control variables shown in Table 6 illustrate a positive and significant association (p-values < 0.05) between AUDIT and CSD_INDEX, which suggests that firms audited by the Big Four auditing firms tend to make more CSD, which is consistent with prior studies (Craswell 1992, Inchausti 1997, Uwuigbe and Egbide 2012). ROA shows positive and significant coefficients ( $\mathrm{p}$-values $<0.10$ ), which suggests that firms that perform better financially are associated with more CSD, which is consistent with the literature (Khan et al. 2013, Lu and Abeysekera 2014, Haniffa and Cooke 2005). The STOCK_EX is positively and significantly (p-values $<0.01$ ) associated with CSD_INDEX, which indicates that firms listed on HOSE engage in significantly higher CSD than firms listed on HNX. This is consistent with $\mathrm{Vu}$ (2012) who examines the factors impacting on voluntary disclosure in Vietnamese listed firms. FOREIGN and STATE are not significantly related to CSD, as in prior studies (Haniffa and Cooke 2005, Lu and Abeysekera 2014).

\section{Additional analysis and robustness tests}

\subsection{Board diversity and corporate social disclosure across four social aspects}

To provide further insight, this study analyses the relationships between board diversity and CSD across four social aspects in the GRI 3.1 framework. These are labor practices, human rights, society, and product responsibility. As is shown in Table 5, information related to labor practices (LAD_INDEX) and product responsibility (PRD_INDEX) items is disclosed the most, with a mean value of 0.17 and 0.16 , respectively. A minimum score of 0 for society (SOD_INDEX) and human rights (HRD_INDEX) aspects suggests that some firms do not disclose any information about their society and human rights aspects; in fact, of the 133 firms in the sample, only 18 firms (13.5\%) disclose the human rights aspect, 74 firms $(55.6 \%)$ 
disclose the society aspect, while all firms (133 firms or 100\%) in the sample disclose the labor and product responsibility aspects.

Following Firth (1979) in omitting firms which definitely do not have any items to disclose, this study examines the impact of board diversity on society aspect disclosure for only the 74 listed firms that disclose the society aspect, whereas it assesses the impact of board diversity on labor aspect disclosure and on product responsibility aspect disclosure for 133 listed firms (full sample). Because only 18 firms disclose the human rights aspect, which does not provide an adequate sample size for regression modeling, the human rights disclosure aspect is not analyzed here. The regression is repeated by replacing CSD_INDEX in the models reported in Table 7 with the score of each of three aspects, i.e., labor practices (LAD_INDEX), product responsibility (PRD_INDEX), and society (SOD_INDEX) as the dependent variable. Because almost identical results are obtained by using either the unweighted or weighted index to measure board diversity, for brevity this study only presents the results using weighted indices of diversity-of-boards and diversity-in-boards. Other results are available upon request.

Table 8 shows that the regression results are consistent with the results of CSD_INDEX reported in Table 7. The results for the disclosure of labor practices (LAD_INDEX), product

3 responsibility (PRD_INDEX), and society (SOD_INDEX) indicate that diversity-of-boards

4 (W_DoB) does not significantly influence the defined aspects of social disclosure. The 5 diversity-in-boards (W_DiB) significantly (p-values < 0.05$)$ and positively influences the 6 defined aspects of social disclosure.

$7 \quad$ Table 8. Board diversity and CSD across three social aspects

\begin{tabular}{lcccccc}
\hline & LAD_INDEX & LAD_INDEX & PRD_INDEX & PRD_INDEX & SOD_INDEX & SOD_INDEX \\
\hline W_DoB & 0.069 & & 0.007 & & 0.073 \\
& $(0.508)$ & & $(0.920)$ & & $(0.317)$ \\
W_DiB & & $0.001 * *$ & & $0.001 * *$ & & $0.001 * * *$ \\
& & $(0.049)$ & & $(0.019)$ & $(0.004)$
\end{tabular}




$\begin{array}{lcccccc}\text { AUDIT } & 0.026 & 0.025 & 0.035 * * & 0.034 * * & 0.010 & 0.009 \\ \text { ROA } & (0.178) & (0.157) & (0.013) & (0.022) & (0.430) & (0.478) \\ & 0.164 * & 0.159 * & 0.077 & 0.074 & 0.130 & 0.128 \\ \text { STOCK_EX } & (0.070) & (0.078) & (0.143) & (0.161) & (0.137) & (0.103) \\ & 0.028 * & 0.027 * & 0.035 * * * & 0.034 * * * & 0.033 * * * & 0.031 * * * \\ \text { FOREIGN } & (0.059) & (0.051) & (0.002) & (0.002) & (0.000) & (0.003) \\ & 0.016 & -0.001 & -0.033 & -0.043 & -0.023 & -0.036 \\ \text { STATE } & (0.778) & (0.992) & (0.352) & (0.244) & (0.590) & (0.368) \\ & -0.008 & 0.015 & -0.026 & -0.009 & -0.003 & 0.018 \\ \text { Constant } & (0.807) & (0.641) & (0.255) & (0.703) & (0.918) & (0.519) \\ & 0.112 * * * & 0.107 * * * & 0.131 * * * & 0.113 * * * & 0.016 & 0.015 \\ \mathrm{R}^{2} & (0.002) & (0.000) & (0.000) & (0.000) & (0.555) & (0.400) \\ \text { Adjusted R } & 0.101 & 0.123 & 0.176 & 0.208 & 0.137 & 0.212 \\ \text { F statistic } & 0.058 & 0.081 & 0.137 & 0.170 & 0.059 & 0.142 \\ \text { p-value } & 2.48 * * & 2.95 * * * & 5.64 * * * & 7.18 * * * & 3.06 * * * & 3.21 * * * \\ \text { Obs } & 0.027 & 0.010 & 0.000 & 0.000 & 0.010 & 0.008 \\ \text { The p-valuen } & 133 & 133 & 133 & 133 & 74 & 74\end{array}$

8 The p-values are in parentheses, calculated using standard errors corrected for heteroscedasticity. Statistical

9 significance is indicated by $* * *, * *$, and * for $1 \%, 5 \%$, and $10 \%$. Please see below Table 5 for description of 10 each variable.

\subsection{Alternative regression specifications}

In the primary analysis, this study measures diversity-in-boards indices (both weighted and unweighted) through the terciles split method. An additional analysis is carried out to ensure that the primary analysis is robust, and this study tests diversity-in-boards and CSD models by using median and quartile values alternately to measure diversity-in-boards indices. These values are used to rank firms' levels of diversity-in-boards (Ben-Amar et al. 2013, Hafsi and Turgut 2013), and those ranks become the diversity-in-board observed in firms. Specifically, the median split method categorizes each demographic attribute into two groups, taking 1 if every value is above the median, otherwise 0 . The quartile split method categorizes each demographic attribute into four groups, taking 0 for the first quartile (below 25\%), 1 for the second quartile (between 25.1\% and 50\%), 2 for the third quartile (between $51 \%$ and $75 \%$ ), and 3 for the fourth quartile (above 75\%). Those results are similar and more significant in the median split method (Table 9). In addition, the results are cross checked using the return on equity (ROE), which measures financial performance, instead of ROA, and the results do not change (Table 9). 


\begin{tabular}{|c|c|c|c|c|}
\hline & CSD_INDEX & CSD_INDEX & CSD_INDEX & CSD_INDEX \\
\hline UW_DiB (median split method) & $\begin{array}{c}0.010 * * * \\
(0.008)\end{array}$ & & & \\
\hline W_DiB (median split method) & & $\begin{array}{c}0.002 * * * \\
(0.010)\end{array}$ & & \\
\hline UW_DiB (quartile split method) & & & $\begin{array}{c}0.004 * * * \\
(0.010)\end{array}$ & \\
\hline W_DiB (quartile split method) & & & & $\begin{array}{c}0.001 * * \\
(0.018)\end{array}$ \\
\hline AUDIT & $\begin{array}{l}0.028 * * * \\
(0.009)\end{array}$ & $\begin{array}{r}0.027 * * \\
(0.011)\end{array}$ & $\begin{array}{r}0.027 * * \\
(0.011)\end{array}$ & $\begin{array}{l}0.027 * * \\
(0.015)\end{array}$ \\
\hline ROE & $\begin{array}{l}0.058^{* *} \\
(0.030)\end{array}$ & $\begin{array}{l}0.058^{* *} \\
(0.028)\end{array}$ & $\begin{array}{l}0.053^{* *} \\
(0.046)\end{array}$ & $\begin{array}{l}0.053^{* *} \\
(0.047)\end{array}$ \\
\hline STOCK_EX & $\begin{array}{c}0.029 * * * \\
(0.000)\end{array}$ & $\begin{array}{c}0.030^{* * * *} \\
(0.000)\end{array}$ & $\begin{array}{c}0.028^{* * *} \\
(0.000)\end{array}$ & $\begin{array}{c}0.028^{* * *} \\
(0.000)\end{array}$ \\
\hline FOREIGN & $\begin{array}{l}-0.018 \\
(0.589)\end{array}$ & $\begin{array}{l}-0.021 \\
(0.534)\end{array}$ & $\begin{array}{l}-0.020 \\
(0.540)\end{array}$ & $\begin{array}{l}-0.022 \\
(0.520)\end{array}$ \\
\hline STATE & $\begin{array}{c}0.008 \\
(0.664)\end{array}$ & $\begin{array}{c}0.008 \\
(0.653)\end{array}$ & $\begin{array}{c}0.010 \\
(0.579)\end{array}$ & $\begin{array}{c}0.009 \\
(0.626)\end{array}$ \\
\hline Constant & $\begin{array}{c}0.013 \\
(0.571)\end{array}$ & $\begin{array}{c}0.013 \\
(0.575)\end{array}$ & $\begin{array}{r}0.034 * * \\
(0.036)\end{array}$ & $\begin{array}{l}0.037 * * \\
(0.024)\end{array}$ \\
\hline $\mathrm{R}^{2}$ & 0.2362 & 0.2355 & 0.236 & 0.2295 \\
\hline Adjusted $\mathrm{R}^{2}$ & 0.1998 & 0.1991 & 0.1996 & 0.1928 \\
\hline $\begin{array}{l}\text { F statistic } \\
\text { p-value } \\
\text { Mean VIF }\end{array}$ & $\begin{array}{c}7.01 * * * \\
0.000 \\
1.25\end{array}$ & $\begin{array}{c}6.99 * * * \\
0.000 \\
1.25\end{array}$ & $\begin{array}{c}6.63 * * * \\
0.000 \\
1.27\end{array}$ & $\begin{array}{c}6.53^{* * *} \\
0.000 \\
1.28\end{array}$ \\
\hline
\end{tabular}

\section{Discussion}

31 The results are consistent with an earlier study by Hafsi and Turgut (2013) who report a

32 positive association between diversity-in-boards and social performance and find no such relationship between diversity-of-boards and social performance. Additionally, it has been shown elsewhere that the structural attributes of a board such as outside directors (Haniffa and Cooke 2002, Hossain and Reaz 2007, Michelon and Parbonetti 2012), board leadership structure (Barako et al. 2006, Haniffa and Cooke 2002, Khan et al. 2013, Michelon and

37 Parbonetti 2012), and directors' ownership (Hafsi and Turgut 2013) do not affect voluntary disclosure or social and environmental disclosure. Based on agency theory, diversity-of- 
boards is identified with structural attributes and therefore represents the recommended governance 'best practices'. Structural attributes of the board can help to align managers' interests with shareholders' interests (Fama 1980, Fama and Jensen 1983). Thus, diversity-ofboards may have only an indirect influence on social disclosure (Hafsi and Turgut 2013).

Also, prior studies document a positive relationship between disclosure (such as social and environmental disclosure or voluntary disclosure) and demographic attributes of the board of directors such as gender diversity (Bear et al. 2010, Fernandez-Feijoo et al. 2012, Post et al. 2011) and education diversity (Akhtaruddin and Abdur Rouf 2011). Based on resource dependence theory, members of the board of directors are key strategic resources for an organization and contribute to CSD. The demographic differences of directors are likely to support an organization's external legitimacy and to enhance the relations between the organization and relevant stakeholders, and therefore diversity-in-boards has a positive impact on CSD.

(1)

\section{Implications}

\subsection{Implications for theory}

The board of directors provides two key functions: it monitor managers' discretion on behalf of the shareholders, as underpinned by agency theory, and provides important resources to the firm, as underpinned by resource dependency theory (Hillman and Dalziel 2003, Jackling and Johl 2009). The findings in this study show that the impact of diversity-of-boards on CSD is not supported by agency theory, while resource dependency theory supports the impact of diversity-in-boards on CSD.

\subsection{Implications for methodology}

Previous studies have mostly considered the individual attributes of the demographic or/and structural attributes of boards when examining their diversity. Those studies seldom combine the attributes. Two studies (Ben-Amar et al. 2013, Hafsi and Turgut 2013) combine the 
demographic attributes into a demographic diversity index, and the structural attributes into a structural diversity index. They assume that all the attributes are equally important. This study however makes no such assumptions. It first examines the attributes by assuming that they are all equally important (unweighted), and then examines the attributes by including firms' executives' perceptions about each of the attributes (weighted). A questionnaire provides executives' perceptions on various attributes relating to board diversity to determine their importance. A comparison of results between weighted and unweighted methods enables the potential impact of the perceived importance of attributes relating to the diversity-in-boards and diversity-of-boards and their relationships with CSD to be investigated.

Additionally, mainstream research has also focused on the quantity of disclosure measured by a dichotomous score (Ho and Wong 2001, Vu 2012, Xiao and Yuan 2007). Little empirical evidence measures the disclosure quality or measures the combined disclosure quantity and disclosure quality (Haji 2013). This study extends the literature by constructing a CSD index that combines disclosure quantity and two aspects of disclosure quality perceived by four socially relevant stakeholder groups, rather than managers or miscellaneous stakeholder perspectives (Haji 2013, McNally et al. 1982, Saleh et al. 2010).

\subsection{Implications for practice}

Based on the survey of different stakeholders, the findings of this study benefit a range of interest groups. Corporate executives, who take charge of preparing CSD, can find the results useful in ascertaining how much and what social information to disclose to stakeholders. The results also demonstrate the current CSD practices of Vietnamese listed firms and stakeholders' perceptions about CSD. Regulators will benefit from a better understanding of Vietnamese firms' CSD practices, to improve the current guidelines on the CSD of Vietnamese listed firms, issued on 15 January 2010 by the Ministry of Finance in its Circular "Guidance for Information Disclosure on Stock Exchange." The year used in the study, 2010, was specifically chosen to best fit this purpose. Although the sample size used in this study is 
just 133 firms, which appears small in the context of large western stock exchanges, in the smaller Vietnamese stock exchange context it is in fact representative.

\section{Conclusions}

Investigating the influence of board diversity on CSD of 133 Vietnamese listed firms in 2010, the findings reject the first hypothesis, that higher diversity-of-boards leads to higher CSD, showing that diversity-of-boards indices (both unweighted and weighted) do not significantly influence the CSD index. Meanwhile, the results support hypothesis 2 which states that greater diversity-in-boards leads to higher CSD. This study also confirmed that weighted and unweighted board diversity indices had a similar influence on CSD. Although no prior studies build weighted and unweighted board diversity indices to make a comparison with this study, other studies that construct both weighted and unweighted disclosure indices in corporate disclosure research also find no significant differences between these two indices (Barako et al. 2006, Chow and Wong-Boren 1987, Haji 2013).

Annual reports are exclusively focused on in this study because they are considered to be firms' most important public communication document. However, social disclosures could also be provided in other ways such as press releases, the media, and the Internet, hence future studies could explore the roles of other disclosure channels to examine firms' CSD.

\section{Appendix.}

\section{Method of measuring unweighted diversity-of-boards index (UW_DoB)}

First, the dissimilarity between a given firm and another firm is measured using a mathematical distance function defined by Han and Kamber (2006) as follows:

$$
d(i, j)=\frac{\sum_{f=1}^{p} \delta_{i j}^{(f)} d_{i j}^{(f)}}{\sum_{f=1}^{p} \delta_{i j}^{(f)}}
$$

where $d(i, j)$ is the dissimilarity between objects $i$ and $j$ (i.e., firm $i$ and firm $j$ ); $p$ is represented as the number of structural attributes of the firm board examined in this study. These two data points are represented as $\left(\mathrm{x}_{\mathrm{i} 1}, \mathrm{x}_{\mathrm{i} 2}, \ldots, \mathrm{x}_{\mathrm{ip}}\right)$ and $\left(\mathrm{x}_{\mathrm{j} 1}, \mathrm{x}_{\mathrm{j} 2}, \ldots, \mathrm{x}_{\mathrm{jp}}\right)$ respectively. 
116 The indicator $\delta_{i j}^{(f)}=1$ with the assumption that attributes $f$ is equal weighted relative to the

117

118

119

120

121

122

123

125

126

127

128

129 contribution.

Then, the contribution made by an attribute $f$ to the dissimilar function between firm $i$ and firm $\mathrm{j}$ (i.e., $d_{i j}^{(f)}$ ) is calculated. However, that computation is unique to each data type. As attributes are measured using different data types, $d_{i j}^{(f)}$ is calculated using different formulas based on the data type of the attribute. The structural attributes of boards in this paper contain binary and ratio scale data types, so the following formulas focus on these two data types:

(a). If attribute $f$ is binary: $d_{i j}^{(f)}=0$ if $\mathrm{x}_{i f}=\mathrm{x}_{j f}$, or otherwise $d_{i j}^{(f)}=1$;

(b). If attribute $f$ is ratio scale, it is treated like an interval scale attribute with the following formula:

$$
d_{i j}^{(f)}=\frac{\left|x_{i f}-x_{j f}\right|}{\max _{h} x_{h f}-\min _{h} x_{h f}} \text { where h runs over all non-missing objects for attribute } f
$$

The contribution of dissimilarity for all the different attributes (i.e., $d_{i j}^{(f)}$ ) is normalized by these formulates, and hence expresses on a common scale from 0 to 1 . The average distance (dissimilarity) to all the other boards is taken as follows (note that 1 is subtracted from the number of firms in the sample in the denominator of the formula because this study compares a firm with other firms without the firm being compared with itself, because such a comparison is meaningless):

$$
D(i)=\frac{\sum_{j=1}^{k} d(i, j)}{k-1}
$$

where $\mathrm{k}$ is the number of firm boards; $\mathrm{D}(\mathrm{i})$ is the average dissimilarity of firm board $\mathrm{i}$ to all other boards in the sample, namely UW_DoB of each firm board. 

data

\begin{tabular}{ccccc}
\hline Firm board & $\begin{array}{c}\text { CEO/chairperson } \\
\text { separation } \\
\text { (binary) }\end{array}$ & $\begin{array}{c}\text { Representative } \\
\text { directors' } \\
\text { ownership }(\%) \\
\text { (ratio scale ) }\end{array}$ & $\begin{array}{c}\text { \% Promoters } \\
\text { (ratio scale ) }\end{array}$ & $\begin{array}{c}\text { Non-executive } \\
\text { directors owning } \\
>5 \% \text { of a firm's } \\
\text { equity } \\
\text { (binary) }\end{array}$ \\
\hline Firm & Attribute 1 & Attribute 2 & Attribute 3 & Attribute 4 \\
\hline 1 & 0 & 0 & 0 & 0 \\
3 & 1 & 0.5726 & 0.6 & 0 \\
4 & 0 & 0 & 0.25 & 0 \\
\hline
\end{tabular}

141 in the dissimilarity matrix as follows:

$$
\left[\begin{array}{cccc}
0 & & & \\
d_{1,2}^{(f)} & 0 & & \\
d_{1,3}^{(f)} & d_{2,3}^{(f)} & 0 & \\
d_{1,4}^{(f)} & d_{2,4}^{(f)} & d_{3,4}^{(f)} & 0
\end{array}\right]
$$

\section{Binary scale data types (Attribute 1 and attribute 4)}

144 Because attributes 1 and 4 are binary, $d_{i j}^{(f)}$ becomes 0 if the attributes of firm board $i$ and firm

145 board $\mathrm{j}$ match, and 1 if the attributes differ. This study gained $d_{i j}^{(f)}$ for attribute 1 (i.e. $\left.d_{i, j}^{(1)}\right)$ in 146 the dissimilarity matrix as follows.

$$
\left[\begin{array}{llll}
0 & & & \\
1 & 0 & & \\
0 & 1 & 0 & \\
0 & 1 & 0 & 0
\end{array}\right]
$$

148 This study gained $d_{i j}^{(f)}$ for attribute 4 (i.e. $d_{i, j}^{(4)}$ ) in the dissimilarity matrix as follows: 


$$
\left[\begin{array}{llll}
0 & & & \\
0 & 0 & & \\
0 & 0 & 0 & \\
1 & 1 & 1 & 0
\end{array}\right]
$$

150

\section{Ratio scale data types (Attribute 2 and attribute 3 )}

152 This illustration computes $d_{i j}^{(f)}$ for attributes 2 and 3 (which are ratio scales). In this scenario, 153 the data of each attribute is treated like an interval scale (see b) for the formula). To compute $154 d_{i j}^{(f)}$ for attribute 2 (i.e. $\left.d_{i, j}^{(2)}\right)$, this study let $\max _{\mathrm{h}} \mathrm{x}_{\mathrm{h}}=0.5726$ and $\min _{\mathrm{h}} \mathrm{x}_{\mathrm{h}}=0$. The following 155 dissimilarity matrix is then obtained for attribute 2 (i.e. $d_{i, j}^{(2)}$ ):

156

$$
\left[\begin{array}{cccc}
0 & & & \\
1 & 0 & & \\
0 & 1 & 0 & \\
0.21 & 0.79 & 0.21 & 0
\end{array}\right]
$$

157 The figures shown in column 1 of the matrix for attribute 2 above (that is $0,1,0,0.21$ ) are 158 calculated as follows.

159 The dissimality score for attribute 2 for firm 1 compared with firm 1:

$160 d_{1,1}^{(2)}=0$ (because there is no dissimilarity between firm 1 and itself).

161 The dissimality score for attribute 2 for firm 1 compared with firm 2:

$$
d_{1,2}^{(2)}=\frac{|0-0.5726|}{0.5726-0}=1
$$

163 The dissimality score for attribute 2 for firm 1 compared with firm 3 :

$$
d_{1,3}^{(2)}=\frac{|0-0|}{0.5726-0}=0
$$

165 The dissimality score for attribute 2 for firm 1 compared with firm 4:

$$
d_{1,4}^{(2)}=\frac{|0-0.1217|}{0.5726-0}=0.21
$$


167 Attribute 3 is also a ratio scale. As with calculating attribute 2 , the $d_{i j}^{(f)}$ for attribute 3 (i.e. $d_{i, j}^{(3)}$ 168 ) in the dissimilarity matrix is as follows (details of calculating individual figures are not 169 shown here):

$$
\left[\begin{array}{cccc}
0 & & & \\
1 & 0 & & \\
0.42 & 0.58 & 0 & \\
0.67 & 0.33 & 0.25 & 0
\end{array}\right]
$$

171

172 The dissimilarity matrices for the four attributes are computed using formula (1). For 173 example, the dissimilarity between firm 1 and firm $4(\mathrm{~d}(1,4))$, for the combined four 174 attributes, is obtained as follows (all four attributes are assumed to have equal weights, hence 175 the indicator $\delta_{i j}^{(f)}$ is 1$)$ :

$$
d(1,4)=\frac{1 * d_{1,4}^{(1)}+1 * d_{1,4}^{(2)}+1 * d_{1,4}^{(3)}+1 * d_{1,4}^{(4)}}{4}=\frac{1 * 0+1 * 0.21+1 * 0.67+1 * 1}{4}=0.47
$$

178 Similarly, the resulting dissimilarity matrix obtained for the data described by the four 179 attributes of mixed types is:

180

$$
\left[\begin{array}{cccc}
0 & & & \\
d(1,2) & 0 & & \\
d(1,3) & d(2,3) & 0 & \\
d(1,4) & d(2,4) & d(3,4) & 0
\end{array}\right]=\left[\begin{array}{cccc}
0 & & & \\
0.75 & 0 & & \\
0.10 & 0.65 & 0 & \\
0.47 & 0.78 & 0.37 & 0
\end{array}\right]
$$

182 Finally, the diversity-of-boards index of each firm board is calculated based on formula (2),

183 which is the average difference of a given firm with all other firms when the dissimilarity

184 distance is measured.

185 For example, the UW_DoB of firm board 1 is:

$$
D(\text { firm } 1)=\frac{d(1,1)+d(1,2)+d(1,3)+d(1,4)}{4-1}=\frac{0+0.75+0.1+0.47}{4-1}=0.44 .
$$


188 Similarly, by using the above computations, the UW_DoB of firm board two, three, and four 189 are $0.73,0.37$, and 0.54 , respectively. These results indicate that firm board 2 is the most 190 diverse (dissimilarity), while firm board 3 is the least diverse (dissimilarity).

191 


\section{References}

Abeysekera, I. and Guthrie, J. 2005. 'An empirical investigation of annual reporting trends of intellectual capital in Sri Lanka'. Critical Perspectives on Accounting, 16:3, 151-63.

Adams, C. A. 2002. 'Internal organisational factors influencing corporate social and ethical reporting: Beyond current theorising'. Accounting, Auditing \& Accountability Journal, 15:2, 223.

Aerts, W., Cormier, D. and Magnan, M. (2008). 'Corporate environmental disclosure, financial markets, and the media: An international perspective'. Ecological Economics, 64:3, 643:659.

Agresti, A. and Agresti, B. F. 1978. 'Statistical Analysis of Qualitative Variation'. Sociological Methodology, 9:Journal Article, 204-37.

Akhtaruddin, M. and Abdur Rouf, M. 2011. 'Corporate Governance, Cultural Factors And Voluntary Disclosure: Evidence From Selected Companies In Bangladesh'. Working Paper, 2011 BAASANA International Conference. Bloomsburg University of Pennsylvania, USA.

Barako, D. G., Hancock, P. and Izan, H. Y. 2006. 'Factors Influencing Voluntary Corporate Disclosure by Kenyan Companies'. Corporate Governance: An International Review, 14:2, 107-25.

Bear, S., Rahman, N. and Post, C. 2010. 'The Impact of Board Diversity and Gender Composition on Corporate Social Responsibility and Firm Reputation'. Journal of Business Ethics, 97:2, 207-21.

Ben-Amar, W., Francoeur, C., Hafsi, T. and Labelle, R. 2013. 'What Makes Better Boards? A Closer Look at Diversity and Ownership'. British journal of management, 24:1, 85-101.

Bernardi, R. A., Bosco, S. M. and Vassill, K. M. 2006. 'Does Female Representation on Boards of Directors Associate With Fortune's "100 Best Companies to Work For" List?'. Business and Society, 45:2, 235-48.

Berthelot, S., Coulmont, M. and Serret, V. 2012. 'Do investors value sustainability reports? A Canadian study'. Corporate Social Responsibility and Environmental Management, 19:6, 355363.

Blau, P. M. 1977. Inequality and heterogeneity : a primitive theory of social structure. New York: Free Press.

Boulouta, I. 2013. 'Hidden Connections: The Link Between Board Gender Diversity and Corporate Social Performance'. Journal of Business Ethics, 113:2, 185-97.

Boyd, B. 1990. 'Corporate linkages and organizational environment: A test of the resource dependence model'. Strategic Management Journal, 11:6, 419-30.

Brammer, S. and Pavelin, S. 2008. 'Factors influencing the quality of corporate environmental disclosure'. Business Strategy and the Environment, 17:2, 120-36.

Bui, T. L. H. 2010. 'The Vietnamese consumer perception on corporate social responsibility'. Journal of International Business Research, 9:SI. 1, 75.

Cormier, D., Ledoux M-J. and Magnan, M. (2011) 'The informational contribution of social and environmental disclosures for investors'. Management Decision, 49:8, 1276-1304

Clarkson, P. M., Fang, X., Li, Y. and Richardson, G. (2013). 'The relevance of environmental disclosures: are such disclosures incrementally informative?' Journal of Accounting and Public Policy, 32:5, 410-431

Chen, C. J. P. and Jaggi, B. 2000. 'Association between independent non-executive directors, family control and financial disclosures in Hong Kong'. Journal of Accounting and Public Policy, 19:4, 285-310.

Cheng, B., loannou, I. and Serafeim, G. 2014. 'Corporate social responsibility and access to finance'. Strategic Journal of Management, 35, 1-23.

Chow, C. W. and Wong-Boren, A. 1987. 'Voluntary Financial Disclosure by Mexican Corporations'. The Accounting Review, 62:3, 533-41.

Cormier, D., Ledoux, M.-J. and Magnan, M. 2011. 'The informational contribution of social and environmental disclosures for investors'. Management Decision, 49:8, 1276-304.

Craswell, A. T. 1992. 'Discretionary Disclosure of Reserves by Oil and Gas Companies: An Economic Analysis'. Journal of Business Finance \& Accounting, 19:2, 295-308.

Dawes, J. 2002. 'Five Point vs Eleven Point Scales: Does it make a difference to data characteristics?'. Australasian Journal of Market Research, 10:1, 39-47.

Demirguc-Kunt, A., Love, I. and Maksimovic, V. 2006. 'Business environment and the incorporation decision'. Journal of Banking and Finance, 30:11, 2967-93. 
Dess, G. G. and Davis, P. S. 1984. 'Porter's (1980) Generic Strategies as Determinants of Strategic Group Membership and Organizational Performance'. The Academy of Management Journal, 27:3, 467-88.

Deza, M. and Deza, E. 2009. 'Encyclopedia of Distances'. Heidelberg: Springer.

Dhaliwal, D. S., Li, O. Z., Tsang, A. and Yang, Y. G. 2011. 'Voluntary Nonfinancial Disclosure and the Cost of Equity Capital: The Initiation of Corporate Social Responsibility Reporting'. The Accounting Review, 86:1, 59-100.

Dhaliwal, D. S., Radhakrishnan, S., Tsang, A. and Yang, Y. G. 2012. 'Nonfinancial Disclosure and Analyst Forecast Accuracy: International Evidence on Corporate Social Responsibility Disclosure'. The Accounting Review, 87:3, 723-59.

Eng, L. L. and Mak, Y. T. 2003. 'Corporate governance and voluntary disclosure'. Journal of Accounting and Public Policy, 22:4, 325-45.

Fama, E. F. 1980. 'Agency Problems and the Theory of the Firm'. The Journal of Political Economy, 88:2, 288-307.

Fama, E. F. and Jensen, M. C. 1983. 'Separation of Ownership and Control'. Journal of Law and Economics, 26:2, 301-25.

Fernandez-Feijoo, B., Romero, S. and Ruiz, S. 2012. 'Does Board Gender Composition affect Corporate Social Responsibility Reporting? 1'. International Journal of Business and Social Science, 3:1.

Firth, M. 1979. 'Impact of size, stock market listing, and auditors on voluntary disclosure in corporate annual reports'. Accounting and Business Research, 9:36, 273.

Galbreath, J. 2011. 'Are there gender-related influences on corporate sustainability?: a study of women on boards of directors'. Journal of management \& organization, 17:1, 17-38.

Gelb, D. and Strawser, J. 2001. 'Corporate Social Responsibility and Financial Disclosures: An Alternative Explanation for Increased Disclosure'. Journal of Business Ethics, 33:1, 1-13.

Gujarati, D. N. and Porter, D. C. 2009. Basic econometrics. Boston: McGraw-Hill Irwin.

Guthrie, J. and Parker, L. 1990. 'Corporate Social Disclosure Practice: A Comparative International Analysis'. Advances in Public Interest Accounting, 3, 159-76.

Hafsi, T. and Turgut, G. 2013. 'Boardroom Diversity and its Effect on Social Performance: Conceptualization and Empirical Evidence'. Journal of Business Ethics, 112:3, 463-79.

Haji, A. A. 2013. 'Corporate social responsibility disclosures over time: evidence from Malaysia'. Managerial Auditing Journal, 28:7, 647-76.

Han, J., Kamber, M. and Ebrary 2006. Data mining: concepts and techniques. Boston: Morgan Kaufmann.

Haniffa, R. and Hudaib, M. 2006. 'Corporate Governance Structure and Performance of Malaysian Listed Companies'. Journal of Business Finance \& Accounting, 33:7-8, 1034-62.

Haniffa, R. M. and Cooke, T. E. 2002. 'Culture, Corporate Governance and Disclosure in Malaysian Corporations'. Abacus, 38:3, 317-49.

Haniffa, R. M. and Cooke, T. E. 2005. 'The impact of culture and governance on corporate social reporting'. Journal of Accounting and Public Policy, 24:5, 391-430.

Harrison, D. A. and Klein, K. J. 2007. 'What's the Difference? Diversity Constructs as Separation, Variety, or Disparity in Organizations'. The Academy of Management Review, 32:4, 1199-228.

Hartley, J. and Betts, L. R. 2010. 'Four layouts and a finding: the effects of changes in the order of the verbal labels and numerical values on Likert-type scales'. International Journal of Social Research Methodology, 13:1, 17-27.

Hillman, A. J. and Dalziel, T. 2003. 'Boards of Directors and Firm Performance: Integrating Agency and Resource Dependence Perspectives'. The Academy of Management Review, 28:3, 383-96.

Ho, S. S. M. and Wong, K. S. 2001. 'A study of the relationship between corporate governace structures and the extent of voluntary disclosure'. Journal of International Accounting, Auditing \& Taxation, 10:2, 139.

Hopkins, M. 2012. The Planetary Bargain: Corporate Social Responsibility Matters. GB: Routledge Ltd.

Hossain, M. and Reaz, M. 2007. 'The determinants and characteristics of voluntary disclosure by Indian banking companies'. Corporate Social Responsibility and Environmental Management, $14: 5,274-88$. 
Inchausti, A. G. 1997. 'The influence of company characteristics and accounting regulation on information disclosed by Spanish firms'. European Accounting Review, 6:1, 45-68.

loannou, I. and Serafeim, G. 2015. 'The impact of corporate social responsibility on investment recommendations: Analysts' perceptions and shifting institutional logics'. Strategic Management Journal, 36:7, 1053-81.

Jensen, M. C. and W. H. Meckling (1976). 'Theory of the firm: Managerial behavior, agency costs and ownership structure'. Journal of Financial Economics, 3, 305-360.

Jackling, B. and Johl, S. 2009. 'Board structure and firm performance: evidence from India's top companies'. Corporate governance, 17:4, 492-509.

Johnson, R. A. and Greening, D. W. 1999. 'The Effects of Corporate Governance and Institutional Ownership Types on Corporate Social Performance'. The Academy of Management Journal, 42:5, 564-76.

Kang, H., Cheng, M. and Gray, S. J. 2007. 'Corporate Governance and Board Composition: diversity and independence of Australian boards'. Corporate Governance: An International Review, 15:2, 194-207.

Khan, A., Muttakin, M. B. and Siddiqui, J. 2013. 'Corporate Governance and Corporate Social Responsibility Disclosures: Evidence from an Emerging Economy'. Journal of Business Ethics, 114:2, 207-23.

Labelle, R., Makni Gargouri, R. and Francoeur, C. 2010. 'Ethics, Diversity Management, and Financial Reporting Quality'. Journal of Business Ethics, 93:2, 335-53.

Lattemann, C., Fetscherin, M., Alon, I., Li, S. M. and Schneider, A. M. 2009. 'CSR communication intensity in Chinese and Indian multinational companies'. Corporate governance, 17:4, 42642.

Lim, S., Z. Matolcsy and D. Chow, (2007). 'The association between board composition and different types of voluntary disclosure'. European Accounting Review 16(3), 555-583.

Love, I. 2011. 'Corporate Governance and Performance around the World: What We Know and What We Don't'. World Bank Research Observer, 26:1, 42-70.

Lu, Y. and Abeysekera, I. 2014. 'Stakeholders' power, corporate characteristics, and social and environmental disclosure: evidence from China'. Journal of Cleaner Production, 64:Journal Article, 426-36.

Mahadeo, J.D., Oogarah-Hanuman, V. and Soobaroyen, T. 2011. 'A longitudinal study of coroporate social disclosures in a developing economy. Journal of Business Ethics, 104, 545-558.

Matolcsy, Z., Tyler, J. and Wells, P. 2012. 'Is continuous disclosure associated with board independence?'. Australian Journal of Management, 37:1, 99-124.

Matsumura, E. M., Prakash, R. and Vera-Muñoz, S. C. 2014. 'Firm-Value Effects of Carbon Emissions and Carbon Disclosures'. The Accounting Review, 89:2, 695-724.

McNally, G. M., Eng, L. H. and Hasseldine, C. R. 1982. 'Corporate Financial Reporting in New Zealand: An Analysis of User Preferences, Corporate Characteristics and Disclosure Practices for Discretionary Information'. Accounting and Business Research, 13:49, 11.

Michelon, G. and Parbonetti, A. 2012. 'The effect of corporate governance on sustainability disclosure'. Journal of management \& governance, 16:3, 477-509.

Milliken, F. J. and Martins, L. L. 1996. 'Searching for Common Threads: Understanding the Multiple Effects of Diversity in Organizational Groups'. The Academy of Management Review, 21:2, 402-33.

Milne,M. J. and Adler, R. W. 1999. 'Exploring the reliability of social and environmental disclosures

content analysis'. Accounting, Auditing \& Accountability Journal, 12:2, 237-256.

Naser, K., Alhussaini, A., Alkwari, D. and Nuseibeh, R. 2006. 'Determinants of Corporate Social Disclosure in Developing Countries: The Case of Qatar'. Advances in International Accounting, 19, 1-23.

Neuendorf, K. A. (2002). The Content Analysis Guidebook. Thousand Oaks, Calif; London: Sage. 
Nguyen, Q. 2012. 'The industry classification for Vietnamese listed firms making investors confused'. http://vietstock.vn/2012/10/phan-nganh-viet-nam-nha-dau-tu-boi-roi-830-244474.htm [in Vietnamese] (accessed 20 February 2016).

Pfeffer, J. and Salancik, G. R. 1978. The external control of organizations: a resource dependence perspective. New York: Harper \& Row.

Post, C., Rahman, N. and Rubow, E. 2011. 'Green Governance: Boards of Directors' Composition and Environmental Corporate Social Responsibility'. Business \& Society, 50:1, 189-223.

Prado-Lorenzo, J.-M., Gallego-Alvarez, I. and Garcia-Sanchez, I. M. 2009. 'Stakeholder engagement and corporate social responsibility reporting: the ownership structure effect'. Corporate Social - Responsibility and Environmental Management, 16:2, 94-107.

Purushothaman, M., Tower, G., Hancock, P. and Taplin, R. 2000. 'Determinants of corporate social reporting practices of listed Singapore companies'. Pacific Accounting Review, 12:2, 101.

Saleh, M., Norhayah, Z. and Muhamad, R. 2010. 'Corporate social responsibility disclosure and its relation on institutional ownership: evidence from public listed companies in Malaysia'. Managerial Auditing Journal, 25:6, 591-613.

Strand, R. 1983. 'A systems paradigm of organizational adaptations to the social environment'. Academy of Management Review, 8, 90-96.

Ullmann, A. A. 1985. 'Data in search of a theory: A critical examination of the relationships among social performance, social disclosure, and economic performance of U.S. firms'. Academy of Management Review, 10:3, 540-557.

Uwuigbe, U. and Egbide, B.-C. 2012. 'Corporate Social Responsibility Disclosures in Nigeria: A Study of Listed Financial and Non-Financial Firms'. Journal of Management and Sustainability, 2:1, 160-69.

Van der Walt, N., Ingley, C., Shergill, G. S. and Townsend, A. 2006. 'Board configuration: are diverse boards better boards?'. Corporate governance, 6:2, 129-47.

Vu, K. A., Tower, G. and Scully, G. 2011. 'Corporate communication for Vietnamese listed firms'. Asian Review of Accounting, 19:2, 125-46.

Vu, K. B. A. H. 2012. 'Determinants of Voluntary Disclosure for Vietnamese Listed Firms'. School of Accounting. Curtin University.

Wang, J. and Coffey, B. S. 1992. 'Board Composition and Corporate Philanthropy'. Journal of Business Ethics, 11:10, 771-78.

World Bank 2015. 'Vietnam, Overview'. The World Bank. http://www.worldbank.org/en/country/vietnam/overview (Accessed on 18 February 2016).

Webb, E. 2004. 'An Examination of Socially Responsible Firms' Board Structure'. Journal of Management and Governance, 8:3, 255-77.

Weetman, P. and Ghazali, N. A. M. 2006. 'Perpetuating traditional influences: voluntary disclosure in Malaysia following the economic crisis'. Journal of international accounting auditing \& taxation, 15:2, 226-48.

White, H. 1980. 'A Heteroskedasticity-Consistent Covariance Matrix Estimator and a Direct Test for Heteroskedasticity'. Econometrica, 48:4, 817-38.

Williams, R. J. 2003. 'Women on Corporate Boards of Directors and Their Influence on Corporate Philanthropy'. Journal of Business Ethics, 42:1, 1-10.

Xiao, H. and Yuan, J. 2007. 'Ownership structure, board composition and corporate voluntary disclosure: Evidence from listed companies in China'. Managerial Auditing Journal, 22:6, 60419.

Yip, E., Staden, C. v. and Cahan, S. 2011. 'Corporate Social Responsibility Reporting and Earnings Management: The Role of Political Costs'. Australasian Accounting Business \& Finance Journal, 5:3, 17-34. 